\title{
Phytotoxic Activity of Cafenstrole on Rice (Oryza sativa L.) and Barnyardgrass (Echinochloa crus-galli (L.) Beauv. var. formosensis Ohwi) Seedlings Emerging from Various Depths and its Behavior in Soil*
}

\author{
Hidenori Takahashi**, Katsuichiro Kobayashi*** and Ie Sung Shim***
}

\begin{abstract}
The phytotoxic activity of cafenstrole [1-(diethylcarbamoyl)-3-(2, 4, 6trimethylphenyl sulfonyl)-1, 2, 4-triazole] on rice and barnyardgrass (Echinochloa crusgalli (L.) Beauv, var. formosensis Ohwi) seedlings emerging from various soil depths was investigated in relation to its behavior in the soil. When cafenstrole was applied into flooding water under water leakage conditions, the growth of rice was markedly inhibited when the seedlings emerged from the top soil layer but scarcely inhibited when they emerged from deeper soil layers. In contrast, the growth of barnyardgrass was remarkably inhibited. In barnyardgrass, the shoot basal part and coronal roots grew in association with the first internode elongation in the soil surface layer from seeds located in layers of various depths. Herbicide-treated layer was clearly formed in the top layer and the herbicide present in the soil water was found only in this layer when cafenstrole was applied into flooding water under water leakage conditions. After soil-mix application with
\end{abstract}

*A part of this work was presented at the 37 th Annual Meeting of the Weed Science Society of Japan, 1998.

**Master's Degree Program in Environmental Sciences, University of Tsukuba, Tsukuba, Ibaraki 305-8572.

***Institute of Applied Biochemistry, University of Tsukuba, Tsukuba, Ibaraki 305-8572.

(Received December 13, 1999, Accepted June 22, 2000) cafenstrole, the herbicide was distributed almost homogeneously in all soil layers, and a sufficient concentration to inhibit plant growth was retained in the soil water of each layer. In this system, the growth of rice seedlings emerging from each layer of soil was similarly inhibited, and not dependent on the emergence depth, as true of barnyardgrass. It was suggested that the phytotoxic activity of cafenstrole on the growth of barnyardgrass depended on its absorption from the herbicide -treated layer through the basal part of the shoot, coronal roots and internode with adventitious roots, regardless of the emergence depth. In addition, the low phytotoxic activity on the growth of rice when the plants were transplanted below the herbicide-treated layer was attributed to the absence of the absorptive parts in the herbicide-treated layer.

Key words: cafenstrole, phytotoxic activity, herbicide in soil water, emergence depth, herbicide-treated layer.

\section{Introduction}

Cafenstrole [1-(diethylcarbamoyl) -3- (2, 4, 6-trimethylphenylsulfonyl)-1, 2, 4-triazole] is a herbicide recently developed for selective control of annual weeds, especially for barnyardgrass (Echinochloa crus-galli (L.) Beauv. var. formosensis Ohwi) in transplant- 
ed rice paddy fields ${ }^{3,4}$. Kanzaki et $a l^{3)}$ showed that inhibition of the growth of barnyardgrass was remarkable when the seeds were placed in and below the soil layers mixed with the herbicide, but was not appreciable when they were placed above the soil. It has been reported that the herbicidal activity of several herbicides on the weeds largely depended on contact with the roots and the basal parts of shoots in the herbicide-treated layer ${ }^{10-12)}$. However, the distribution of cafenstrole in soil has not yet been investigated in relation to its herbicidal activity.

Barnyardgrass is one of the most troublesome annual weeds in paddy fields in Japan. It has been reported that barnyardgrass can emerge from soil of $8 \mathrm{~cm}$ depth under suitable soil moisture conditions ${ }^{5}$, and that this emergence depended mostly on the elongation of the first internode with coronal roots to the topmost layer of soil, regardless of the depth at which the seeds were planted in the soil ${ }^{11}$. It has been suggested that the selectivity of cafenstrole between transplanted rice and barnyardgrass might be induced by "placement selectivity" independent of the emergence depth of the weeds in paddy fields ${ }^{3}$. However, no information is available about the effect of cafenstrole on the growth of seedlings emerging from various soil depths or about its behavior in soil in relation to the selective phytotoxic activity. It was revealed that the phytotoxic activity of herbicides applied to soil was induced by their concentration in soil water but not by the total amount in soil ${ }^{6-9}$.

The objective of the present study was to evaluate the behavior of cafenstrole in soil and its concentration in soil water in relation to its phytotoxic activity on the growth of rice and barnyardgrass seedlings emerging from various soil depths.

\section{Materials and Methods}

\section{Plant materials and bioassay}

Air-dried, sieved Yawara paddy soil (light clay, organic carbon content $2.71 \%$ and CEC $16.0 \mathrm{~cm}(+) / \mathrm{kg})^{9)}$, and rice (Oryza sativa $\mathrm{L}$. cv. Nipponbare) and barnyardgrass (Echinochloa crus-galli (L.) Beauv. var. formosensis Ohwi) were used in this study. Rice and barnyardgrass seeds, in which the dormancy had bee broken, were placed on a filter paper moistened with water for germination in a petri dish at $30{ }^{\circ} \mathrm{C}$ under a dark condition. The germinated seeds of both plant species were planted at $0-, 1.0^{-}$. and $2.0-\mathrm{cm}$ depths in soil in polyethylene pots $(10.5 \mathrm{~cm}$ in height and $3.1 \mathrm{~cm}$ in diameter) and placed in an incubator $\left(25{ }^{\circ} \mathrm{C}\right.$ in 14 hours-illumination at about $280 \mu \mathrm{E} / \mathrm{m}^{2} / \mathrm{sec}$. and $20{ }^{\circ} \mathrm{C}$ in the dark for 10 hours) for 8 to 10 days until the seedlings reached the 2-leaf stage, and then they were washed gently with water and used for the bioassays.

Cafenstrole application to soil was conducted by two different methods, soil-surface application and soil-mix application. In soilsurface application, the air-dried soil was put into a polyethylene pot with holes at the bottom, which was composed of two parts lengthwise. The soil was supplied with water and puddled in the pot, the pots were allowed to stand for 24 hours, and then the flooding water was kept at $1 \mathrm{~cm}$ by adding it from the bottom. By dividing the pot into two parts, the rice and barnyardgrass seedlings were transplanted to soil at the depth corresponding to the emergence depth in the previous culture; the seeds were placed just below each planting depth and the roots were located at a lower depth than the seeds. Cafenstrole dissolved in acetone was applied at a dosage of $600 \mathrm{~g}$ a. i./ha into flooding water to reach a $2 \mathrm{~cm}$ depth with a final acetone concentra- 
tion of $1 \%$. Water leaked from the bottom of the pot at the rate of $1.5 \mathrm{~cm} /$ day every day and the same volume of water was supplemented into the flooding water.

In soil-mix application, $200 \mathrm{~g}$ of the soil was put into $500 \mathrm{ml}$ of aqueous cafenstrole solution at a concentration of $3 \times 10^{-5} \mathrm{M}$ with $1.0 \%$ acetone, and mixed thoroughly in a beaker (the soil sample is hereafter referred to as applied-soil). The applied-soil was put into polyethylene pots without holes in the bottom, the pots were allowed to stand for 24 hours and the paddy water was pipetted off until the depth was several mm. Transplanting of the seedlings was conducted as in the case of similarly to soil-surface application.

In both bioassays, the pots were placed in the incubator for 4 days and the shoot length of each seedling was measured, since the effect of cafenstrole on shoot elongation is an important parameter of phytotoxic activity $^{3}$. Shoot elongation of each seedling was calculated by subtracting the initial length from the shoot length measured at the end of the bioassay. Experiments were carried out with three replications.

\section{Distribution of cafenstrole in soil}

Distribution of cafenstrole in soil was examined by the soil-surface and soil-mix applications, as described above. In both experiments, a column composed of 10 pieces of a vinyl chloride ring ( $1 \mathrm{~cm}$ in height and 10 $\mathrm{cm}$ in diameter) was used ${ }^{13)}$, instead of the polyethylene pot in the bioassays.

In both applications, the soil in the pot was divided into $1 \mathrm{~cm}$ segments at designated days after the treatment. Each soil layer was centrifuged in double tubes at $13,000 \times \mathrm{g}$ to separate the soil water collected in the outer tube and the soil remaining in the inner tube ${ }^{6}$ ) (hereafter referred to as "centrifuged-soil"). After centrifugation, the soil water was immediately prepared for high performance liquid chromatographic (HPLC) analysis. Cafenstrole in the centrifuged-soil was extracted with acetonitrile and the extracted solution was used for HPLC analysis. The amount of cafenstrole was determined using a HPLC (Shimadzu 10 A liquid chromatograph) equipped with a Tosoh Inertsil ODS2 analytical column (a $250 \times 4.6 \mathrm{~mm}$ ), a Shimadzu UV spectrophotometric detector operating at $242 \mathrm{~nm}$ and a chromatocorder. The mobile phase $(1 \mathrm{ml} / \mathrm{min})$ was composed of acetonitrile and water $(60: 40, \mathrm{v} / \mathrm{v})$. The detectable limit of cafenstrole was $0.03 \mathrm{nmol} /$ $\mathrm{ml}$ and the recovery exceeded $90 \%$. The amount of cafenstrole adsorbed on the soil solid in the centrifuged-soil was calculated in the same way as in the previous report ${ }^{7)}$. All the treatments were conducted with three replications.

\section{Results and Discussion}

The phytotoxic activity of cafenstrole by soil-surface application on the shoot elongation of both plant species is shown in Fig. 1 . In rice, the growth of the seedlings emerging from the soil surface was markedly inhibited while that of seedlings emerging from a depth of 1 and $2 \mathrm{~cm}$ was hardly inhibited. On the contrary, the growth of barnyardgrass seedlings was strongly inhibited regardless of the emergence depth although the inhibition degree was slightly lower for those emerging from the deeper layers than for those emerging from the surface. In the top soil layer, the basal part of shoot, coronal roots and first internode with roots of barnyardgrass was observed, regardless of the emergence depth, as reported by Dawson ${ }^{1)}$ while these parts of rice seedlings were not present. These results indicated that the susceptibility of rice depended on the emergence depth unlike that of barnyardgrass, supporting the assumption 


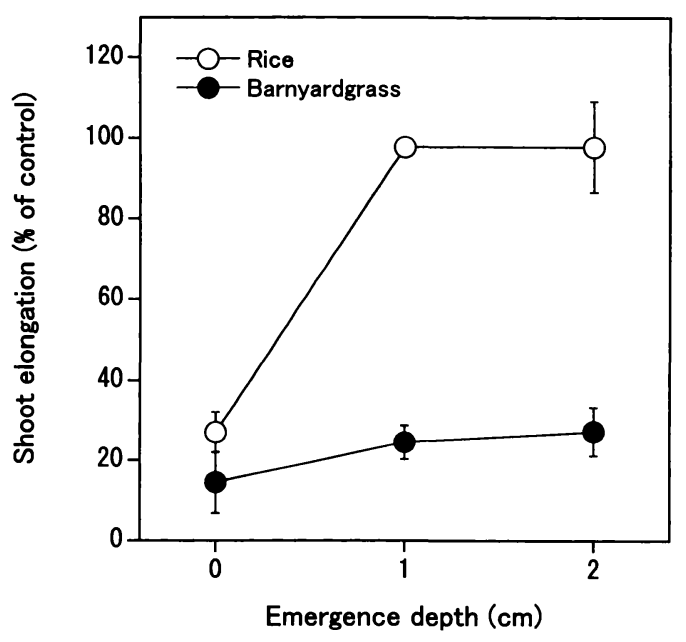

Fig. 1. Effect of cafenstrole on shoot elongation of rice and barnyardgrass seedings emerging from different depths in Yawara soil at 4 days after soil-surface application.

Vertical bars represent the SE of the mean. Mean shoot elongation values ( $\mathrm{mm}$ ) for each group of control seeding were $100.0 \pm 4.9$ at 0 $\mathrm{cm}, 132.7 \pm 8.4$ at $1 \mathrm{~cm}$ and $132.3 \pm 11.9$ at $2 \mathrm{~cm}$ in rice, and $37.8 \pm 8.0$ at $0 \mathrm{~cm}, 52.7 \pm 2.9$ at 1 $\mathrm{cm}$ and $49.1 \pm 7.9$ at $2 \mathrm{~cm}$ in barnyardgrass, respectively.

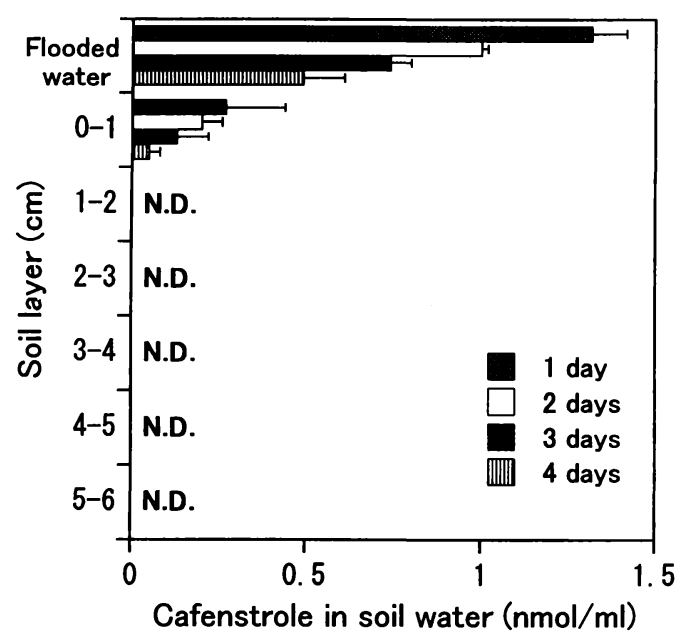

that the selectivity of cafenstrole between barnyardgrass and transplanted rice in paddy fields was mainly due to the lack of absorptive parts in rice, when the plants were transplanted in deeper soil layers ${ }^{2,4}$. Figure 2 shows the downward mobility of cafenstrole in soil after soil-surface application. In the flooding water, the concentration was the highest 1 day after the application and it decreased with time. Cafenstrole was detected in the $0-1 \mathrm{~cm}$ layer but not in the deeper soil layers. The amount of cafenstrole adsorbed on soil solid scarcely decreased with time whereas the concentration in soil water decreased remarkably. These results demonstrated that little downward mobility of cafenstrole occurred in soil under a water leakage condition, resulting in the topmost formation of the herbicide-treated layer, as observed with thenylchlor [2-chloro- $N$ - (3methoxy-2-thienyl) methyl-2', 6'-dimethylacetanilide $]^{13)}$ and pretilachlor [2-chloro2', 6'-diethyl - $N$ - (2-propoxyethyl) acetanilide $]^{9)}$. It was reported that the

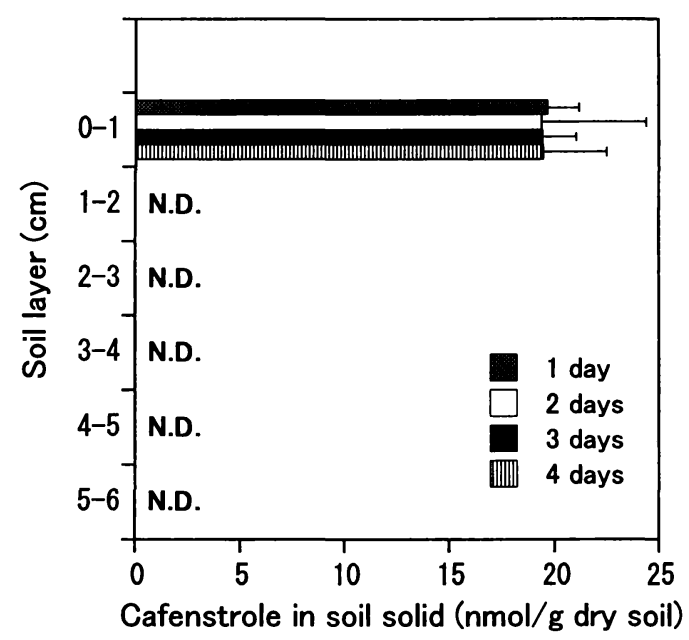

Fig. 2. Time course of the distribution of cafenstrole in soil water (left) and soil solid (right) in Yawara soil after soil-surface application.

N.D.: not detected

Vertical bars represent the SE of the mean. 


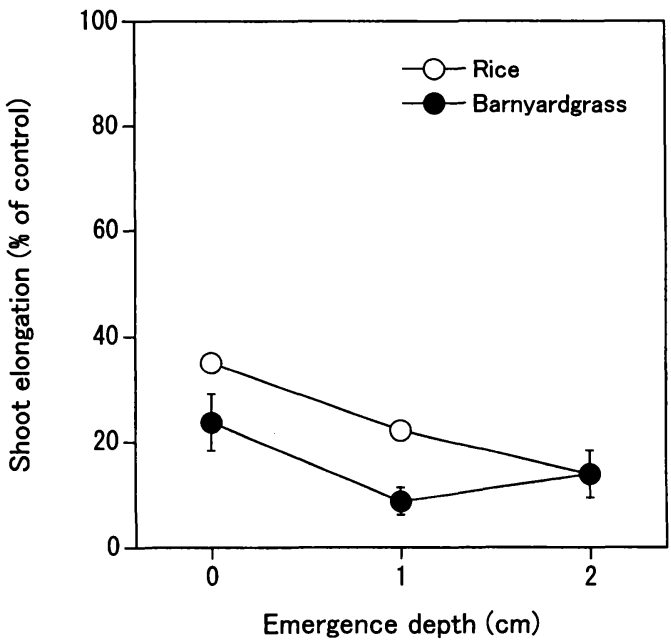

Fig. 3. Effect of cafenstrole on shoot elongation of rice and barnyardgrass seedlings emerging from different depths in Yawara soil at 4 days after soil-mix application.

Vertical bars represent the SE of the mean. Mean shoot elongation values ( $\mathrm{mm}$ ) for each group of control seedings were $89.1 \pm 2.9$ at 0 $\mathrm{cm}, 90.7 \pm 10.0$ at $1 \mathrm{~cm}$ and $87.0 \pm 3.6$ at $2 \mathrm{~cm}$ in rice, and $25.9 \pm 4.3$ at $0 \mathrm{~cm}, 51.8 \pm 4.3$ at $1 \mathrm{~cm}$ and $45.8 \pm 3.5$ at $2 \mathrm{~cm}$ in barnyardgrass, respectively.

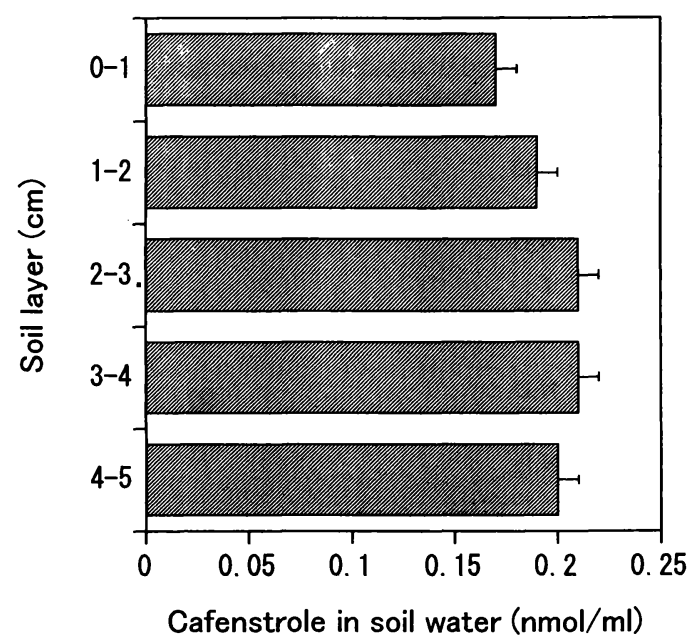

phytotoxic activity of cafenstrole induced by contact with the foliage was very $l_{0}{ }^{3}$. These findings suggested that cafenstrole present in soil water in the herbicide-treated layer was absorbed by barnyardgrass in sufficient amount to induce inhibition independent of the emergence depth, in contrast to rice which emerged from the soil below the herbicide-treated layer.

With the soil-mix application, inhibition of the growth of barnyardgrass by cafenstrole was slightly more for the seedling emerging from deeper layers, as in the case of rice (Fig. 3 ). The inhibition degree was slightly greater in barnyardgrass than in rice. These results indicated that the inhibition of growth of both plants by cafenstrole was not closely associated with their emergence depth from soil, suggesting that rice seedlings showed a remarkable susceptibility to cafenstrole when the herbicide was applied throughout the soil in which the shoot basal parts and the roots were present, as true of barnyardgrass. Figure 4 shows that the distribution of cafen-

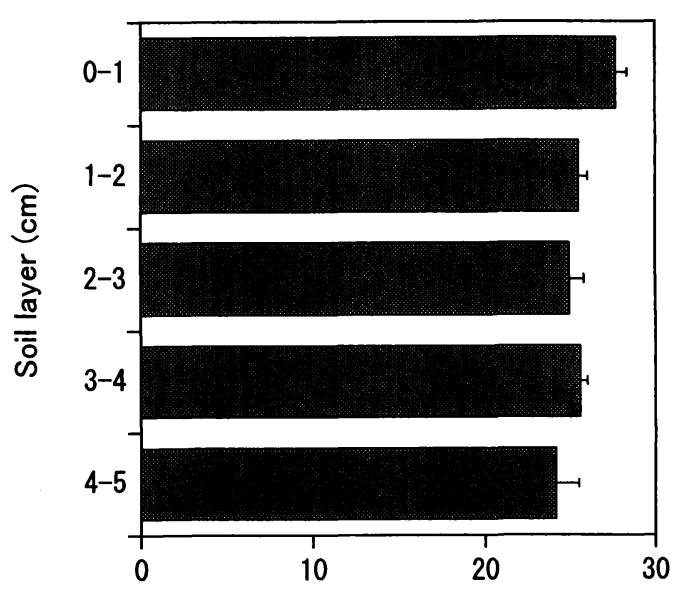

Cafenstrole in soil solid ( $\mathrm{nmol} / \mathrm{g}$ dry soil)

Fig. 4. Distribution of cafenstrole in soil water (left) and soil solid (right) in Yawara soil at 1 day after soil-mix application.

Vertical bars represent the SE of the mean. 
strole distribution throughout the soil layers was similar, although the concentration in soil water in the upper layers was slightly lower than that in deeper layers in contrast to the adsorption on soil solid. The lower concentration in soil water in the $0-1 \mathrm{~cm}$ layer coincided with the lower phytotoxic activity on the growth of both plant species in this soil layer, as shown in Fig. 3. These findings suggested that the growth of the seedlings emerging from different depths was inhibited to a similar extent in both plant species by the absorption of cafenstrole existing in the soil water in the applied-soil. The slight difference in the concentration between the top layer and the other layers could not be elucidated, but it is important to note that there was a difference in the susceptibility between rice and barnyardgrass when the absorptive parts of the plant similarly contacted the cafenstrole present in the layers.

The present study demonstrated that, when the seeds emerged from deeper soil layers under a water leakage condition, the higher susceptibility of barnyardgrass than rice to cafenstrole applied into flooding water depended on the higher absorption of the herbicide present in the soil water by the basal part of shoot, coronal roots and internode with adventitious roots located in the herbicide-treated layer. These findings prove the placement selectivilty of cafenstrole in paddy fields $^{2-4)}$ in terms of its behavior in soil. On the other hand, the tolerance of transplanted rice to the herbicide in paddy fields seemed to be due to its lack of absorptive parts in the herbicide-treated layer. It is important to emphasize that, regardless of the emergence depth, the high susceptibility of barnyardgrass to cafenstrol was presumably induced by absorption of the herbicide in soil water in the herbicide-treated layer through the plant's absorptive parts in the topmost layer in association with the elongation of its first internode; this led to induction of the selectivity between transplanted rice and barnyardgrass in paddy fields.

Acknowledgment: The authors are grateful to Eikou Kasei Co., Ltd. for the gift of cafenstrole.

\section{References}

1) Dawson, J. H. 1963. Development of barnyardgrass seedlings and their response to EPTC. Weeds 11, 60-67.

2) Kanzaki, M, K. Torio, N. Shirakawa, Y. Iwane, H. Kuramochi and M. Konnai 1993. Herbicidal activity of new carbamoyl triazole compounds, 4: Factors affecting phytotoxic activity of $\mathrm{CH}-900$ on weeds and rice. Weed Res. Japan 38(Suppl), 40-41. (in Japanese)*

3 ) Kanzaki, M, K. Torio, M. Takeuchi, N. Shirakawa, H. Kuramochi and M. Konnai 1994. Herbicidal activity of new carbamoyl triazole compounds, 6: Herbicidal activity of $\mathrm{CH}-900$ on several treatment conditions. Weed Res. Japan 39 (Suppl), 28-29. (in Japanese)

4) Kanzaki, M, M. Takeuchi and N. Shirakawa 1999. Chemical structure and herbicidal activity of 1, 2, 4-triazole-carboxamide derivatives. Weed Res. Japan 44(2), 139-143. (in Japanese with English summary)

$5)$ Kataoka, T. and S. Y. Kim 1978. Emergence depth of seeds of several weeds (in Japanese with English summary). Weed Res. Japan 23(1), 1319.

$6)$ Kobayashi, K., M. Onoe and H. Sugiyama 1994. Thenylchlor concentration in soil water and its herbicidal activity. Weed Res., Japan 39(3), 160164.

7 ) Kobayashi, K., N. Nakamura, I. S. Shim and S. Nagatsuka 1996. Relationship of herbicidal activity of soil-applied mefenacet to its concentration in soil water and adsorption in soil. Weed Res., Japan 41 (2), 98-102.

*Translated from the Japanese by the present authors. 
8) Kobayashi, K., Y. Tsukasaki, S. Tongma and I. S. Shim 1999. Phytotoxic activity of chlomeprop in soil and concentration of its hydrolyzed metabolite DMPA in soil water. Pestic. Sci. 55 (4), 474-478.

9) Kobayashi, K., N. Ashida and I. S. Shim 1999. Pretilachlor behavior and its phytotoxic activity on transplanted rice in Utsunomiya paddy soil. J. Weed Sci. Tech. 44(4), 285-292.

10) Mester, T. and D. D. Buhler 1990. Effect of planting depth on velvetleaf (Abutilon theophrasati) seedling development and response to cyanazine. Weed Sci. 38(1), 34-38.
11) Murakami, S 1990. Glasshouse study on herbicidal activity of pretilachlor on rice and Echinochloa oryzacola Vasing. Weed Res. Japan 35(2), 155-163.

12) Ogasawara, M., M. Konnai, T. Takematsu, S. Kato and M. Ishizaki 1989. Properties of a new herbicide, NSK-850 (in Japanese with English summary). Weed Res. Japan 34(2), 138-145.

13) Onoe, M., D. J. Lee, K. Kobayashi and H. Sugiyama 1995. Herbicidal activity of soilapplied thenylchlor and its mobility in two paddy soils. Weed Res., Japan 40(2), 75-79.
出芽深度の異なるイネおよびヒメタイヌビエの 生育に対するカフェンストロールの作用と土㙥 中における挙動

高橋秀典* ・ 小林勝一郎***沈 利星 ${ }^{* *}$

\section{摘 要}

異なる土壌深度から出芽したイネおよびヒメタイ ヌビエの生育に対するカフェンストロールの作用と 本剤の土壌中における挙動との関係を解析した。

減水条件下の田面水に本剤の水溶液を添加した場 合（土壌表面処理）には，イネでは表層近傍から出 芽したものは強い生育阻害を受けたものの, 出芽深 度の深いものは阻害されなかった。これに対し, ヒ メタテヌビエでは, いずれの深度から出芽しても強 く阻害された (Fig. 1)。この時, ヒメタイヌビエで は出芽深度にかかわりなく表層近傍には種子より抽 出した不定根, 中胚軸および茎葉基部が観察された が, イネでは植えつけた種子の深度付近にのみ茎葉 基部が存在していた。この条件下では, 本剤は土壌 表層に「除草剤処理層」を形成し, 処理後の日数に

\footnotetext{
*筑波大学環境科学研究科
}

**筑波大学応用生物化学系
関わりなく固相吸着態および土畩水溶存態のいずれ もが $1 \mathrm{~cm}$ 以下に存在が認められなかった (Fig. 2)。 また, 田面水中および土壤水中における溶存態の濃 度は経時的に低下した。

本剤を土壌と均一に混合した場合(土壤混和処理) には, ヒメタイヌビエは土壊表面処理の場合と同様 な生育阻害が認められ, さらに, イネでも, やや感 受性が劣るものの, いずれの深度から出芽しても強 い生育阻害が認められた (Fig. 3)。この土壌混和処 理の場合, 本剤は固相への吸着態および土壌水中で の溶存のいずれにおいても土培深度にかかわらずほ ほ均一に分布していた (Fig. 4)。

これらの結果から, 土壤表面処理において, 出芽 深度にかかわりなく認められるヒメタイヌビエのカ フェンストロールに対する高い感受性は, 出芽に伴 って形成され，土壌表層の「除草剤処理層」に存在 する上記諸器官によって本剤が土壌水中から吸収さ れることにより発現し, また，こうした器官を形成 しないイネを除草剤処理層より下に移植した場合に は両植物間において顕著な選択性が発現されるもの と想定された。

キーワード : カフェンストロール, 殺草活性, 土壤 水中濃度, 出芽深度, 除草片処理層 